\title{
Determining the Homogeneity and Stand Quality Values in Pure Oriental Spruce (Picea orientalis (L.) Link.) Grown in Turkey
}

\author{
Ercan Oktan* \\ Karadeniz Technical University, Faculty of Forestry, Department of Silviculture, \\ 61080 Trabzon, Turkey
}

Received: 17 January 2018

Accepted: 20 March 2018

\begin{abstract}
The forests of the eastern Black Sea in Turkey are populated by Oriental spruce (Picea orientalis (L.) Link.), a heterogeneous species in terms of the quality of wood. Oriental spruce forests have been managed and used for lumbering in lack of consideration of the homogeneity of the trees. Furthermore, it is necessary to know what kinds of Oriental spruce have been found and which of them produce best quality of wood so that future improvement can be planned accordingly. In this work, a quantitative value developed. Homogeneous index (HI) and stand quality values (SQV) are calculated from the sample plots taken from 75 areas. The HI value varied from 1,95 to 6,74 in the even-aged stands, and 1,88-7,15 in uneven-aged stands. For both structures, $\mathrm{HI}=3$ value can be accepted as a general selective range. SQV values range 2,16-4,83 in even-aged stands and 3,47-4,77 in uneven-aged stands. According to regression analysis, mathematical models, and SQV, there are no statistically significant differences between the aspect and slope, but there is a positive correlation among the height, stand volume, and age. According to the results, homogeneous index is a classification method that can be used for discrimination of stands. Moreover, the operation of pure spruce stand according to uneven-aged management principles will contribute to the formation of better quality and stable stands.
\end{abstract}

Keywords: homogeneous index, stand quality values, Oriental spruce, wood quality

\section{Introduction}

Oriental spruce is one of particular spruce species in Turkey and is spread between $40^{\circ} 23^{\prime}-43^{\circ} 50^{\prime}$ northern latitude and $37^{\circ} 40^{\prime}-44^{\circ} 13^{\prime}$ eastern longitude. 135,959 ha. of total 350.000 is purely populated by the Oriental spruce [1,2]. Only 82,361 ha of 135,959 ha

*e-mail: oktan@ktu.edu.tr contain industrial-quality trees, and the rest is known as an unproductive area [3].

In Turkey, all pure oriental spruce forests have been managed without considering ages and structures of the trees. This limits diversity that might have occurred. On the other hand, the determination of stand structures has brought up the importance of stand structure $[4,5]$.

Stand is forest ecosystem itself and the basis of a forest in respect of constituting the least unit and it means production, maintenance-regeneration, and protection activities [6]. When using the number of 
trees, basal area, total volume, and volume increment to determine the stand structure, quality value should be taken into consideration too [7-10]. Knowing the quality of a stand with all its value has gained importance especially in stands that consist of timber production forests [11-14].

The structures of the trees, growth characteristics, and homogeneity index values (Lorenz curve) can be determined according to the parameters described by De Camino [15] and Gehrlein [16]. These Lorenz curve values, which can be obtained by frequent measurement of the trees in the forest, should be used to determine the quality of the trees [17]. However, in the near future, it is very difficult to make such comparisons by periodic measurements. However, it is crucial to know the recent quality of the forest to make plans for the future [18, 19]. A quantitative value is easy to understand and can be used. The limitation of getting these values is that the trunk of a tree should be divided into 4 equal volumes [17].

In this paper, we developed a quantitative value to assess the quality and homogeneity of Oriental spruce found in the forests of the eastern Black Sea and later to apply this method for other tree species naturally grown in the same region.

\section{Material and Methods}

\section{Study Area}

The samples are taken from the pure spruce found in untreated or poorly treated natural forest dynamics, and in normal canopy. Giresun, Rize, Trabzon, and Artvin districts in the eastern Black Sea Region of Turkey were selected for sample plots. Fifty-nine of a total of 75 sample plots were taken from the even-aged trees and the rest of the 16 samples were from trees with uneven ages (Fig. 1).

Sample plot areas ranged 400-700 $\mathrm{m}^{2}$. General information related to the sample plots is listed in Table 1. Diameters at breast height, ages, and heights of the trees in these sample plots were measured (Table 1).

Age measurements were made by increment cores. All trees in the sample plots were divided into 4 equal parts by a special marked meter from below to up [20]. In addition, every tree in the plot was socially classified by IUFRO criteria [21, 22].

\section{Methods}

The Lorenz curve is based on establishing the relationship between the number of individuals in a definite social category and their percentage in a total population. If two social categories have the same percentage and number in a population, their distributions are also equal and homogeneous. Since a stand is also a population, the number of trees and their volumes can evaluate the number of individuals and total income. From this point of view, the homogeneous index (HI) can be determined by equation $1[15,16,23,24]$.

HI can be calculated by the equation below:

$$
H I=\frac{\sum_{i=1}^{n-1} \sum_{i=1}^{n-1} \% P_{i}}{\sum_{i=1}^{n-1} \sum_{i=1}^{n-1} \% P_{i}-\sum_{i=1}^{n-1} \sum_{i=1}^{n-1} \% V_{i}}
$$

HI: Homogeneity index

$\% \mathrm{Pi}$ : Cumulative relative frequency values of tree numbers

$\% \mathrm{Vi}$ : cumulative relative frequency values of tree volumes

$\mathrm{n}$ : number of diameter class

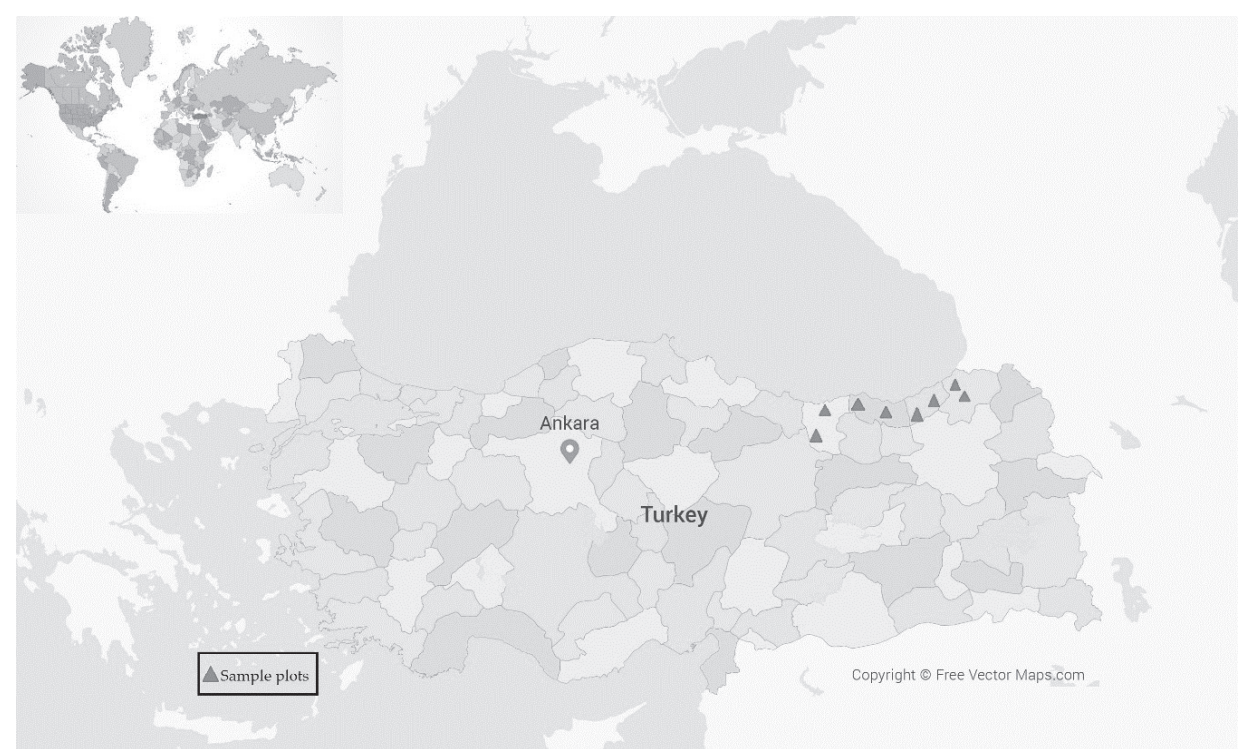

Fig. 1. Map of the research areas. 
Table 1. General information about the sample plots.

\begin{tabular}{|c|c|c|c|c|c|c|c|c|c|}
\hline $\begin{array}{l}\text { Sample } \\
\text { Plot }\end{array}$ & Aspect & $\begin{array}{l}\text { Altitude } \\
\text { (m) }\end{array}$ & $\begin{array}{l}\text { Slope } \\
(\%)\end{array}$ & $\begin{array}{l}\text { Number of trees } \\
\text { (ha) }\end{array}$ & $\begin{array}{l}\text { Mean height } \\
\text { (m) }\end{array}$ & $\begin{array}{l}\text { Volume } \\
\left(\mathrm{m}^{3} / \mathrm{ha}\right)\end{array}$ & $\begin{array}{l}\text { Stand } \\
\text { Age }\end{array}$ & $\begin{array}{l}\text { Site quality Index } \\
\text { (m) }\end{array}$ & Stand structure \\
\hline 1 & $\mathrm{~N}$ & 1110 & 45 & 1587 & 15,1 & 328,39 & $61^{*}$ & 29,69 & Uneven-aged \\
\hline 2 & $\mathrm{NE}$ & 1050 & 35 & 1253 & 16,5 & 370,45 & $73^{*}$ & 27,36 & Uneven-aged \\
\hline 3 & SW & 1745 & 40 & 743 & 22,0 & 763,46 & 119 & 21,94 & Even-aged \\
\hline 4 & S & 1700 & 45 & 943 & 21,3 & 883,96 & $111^{*}$ & 22,63 & Uneven-aged \\
\hline 5 & S & 1755 & 25 & 843 & 21,8 & 812,00 & 127 & 23,96 & Even-aged \\
\hline 6 & W & 1800 & 35 & 957 & 18,6 & 793,60 & 127 & 21,23 & Even-aged \\
\hline 7 & SW & 1820 & 25 & 2350 & 13,5 & 723,95 & $95^{*}$ & 20,55 & Uneven-aged \\
\hline 8 & $\mathrm{~N}$ & 1730 & 60 & 2400 & 14,5 & 506,83 & $62^{*}$ & 25,17 & Uneven-aged \\
\hline 9 & NW & 1771 & 40 & 1150 & 21,5 & 934,03 & 119 & 22,34 & Even-aged \\
\hline 10 & SW & 1425 & 15 & 1225 & 20,2 & 1025,85 & $102^{*}$ & 24,98 & Uneven-aged \\
\hline 11 & S & 1706 & 15 & 3225 & 13,8 & 1066,38 & $87^{*}$ & 27,52 & Uneven-aged \\
\hline 12 & SW & 1673 & 60 & 1750 & 18,8 & 915,28 & 87 & 25,14 & Even-aged \\
\hline 13 & $\mathrm{NE}$ & 1619 & 65 & 1250 & 17,8 & 745,45 & $80^{*}$ & 23,60 & Uneven-aged \\
\hline 14 & NW & 1826 & 65 & 1950 & 16,8 & 1098,22 & 99 & 25,76 & Even-aged \\
\hline 15 & $\mathrm{~N}$ & 1806 & 25 & 1825 & 13,5 & 531,28 & 92 & 20,06 & Even-aged \\
\hline 16 & $\mathrm{E}$ & 1840 & 33 & 1425 & 23,2 & 896,88 & 116 & 22,35 & Even-aged \\
\hline 17 & NW & 1717 & 75 & 1283 & 21,8 & 703,72 & 83 & 28,78 & Even-aged \\
\hline 18 & SW & 1495 & 55 & 2975 & 14,8 & 480,80 & $57^{*}$ & 29,07 & Uneven-aged \\
\hline 19 & $\mathrm{NE}$ & 1776 & 55 & 1950 & 15,8 & 917,13 & $78^{*}$ & 27,77 & Uneven-aged \\
\hline 20 & $\mathrm{NE}$ & 1285 & 45 & 2000 & 14,8 & 540,15 & 89 & 22,89 & Even-aged \\
\hline 21 & NW & 1516 & 40 & 1700 & 22,3 & 1427,20 & 95 & 27,11 & Even-aged \\
\hline 22 & NW & 1550 & 65 & 1650 & 20,9 & 928,65 & 101 & 25,14 & Even-aged \\
\hline 23 & SW & 1489 & 20 & 1200 & 22,2 & 1363,80 & 119 & 23,23 & Even-aged \\
\hline 24 & $\mathrm{~W}$ & 1586 & 20 & 950 & 22,4 & 947,11 & 88 & 28,46 & Even-aged \\
\hline 25 & $\mathrm{NE}$ & 1827 & 45 & 1625 & 20,7 & 865,10 & 79 & 26,71 & Even-aged \\
\hline 26 & SE & 1724 & 25 & 1875 & 16,6 & 704,78 & 73 & 24,82 & Even-aged \\
\hline 27 & NW & 1525 & 50 & 1625 & 21,4 & 1316,18 & 95 & 29,74 & Even-aged \\
\hline 28 & $\mathrm{NE}$ & 1000 & 45 & 1500 & 18,3 & 942,58 & 75 & 25,89 & Even-aged \\
\hline 29 & SE & 950 & 45 & 1500 & 16,4 & 757,50 & 78 & 25,64 & Even-aged \\
\hline 30 & $\mathrm{NE}$ & 1584 & 50 & 2117 & 15,1 & 533,93 & $79^{*}$ & 23,31 & Uneven-aged \\
\hline 31 & $\mathrm{NE}$ & 1862 & 60 & 1425 & 14,9 & 719,28 & 97 & 18,38 & Even-aged \\
\hline 32 & SE & 1860 & 45 & 3050 & 16,1 & 835,70 & 81 & 28,40 & Even-aged \\
\hline 33 & S & 1710 & 35 & 1300 & 24,5 & 676,08 & 117 & 32,51 & Even-aged \\
\hline 34 & S & 1350 & 40 & 1533 & 22,0 & 661,03 & 74 & 34,90 & Even-aged \\
\hline 35 & W & 1800 & 50 & 1850 & 19,3 & 1109,72 & 86 & 27,14 & Even-aged \\
\hline 36 & SW & 1920 & 65 & 2550 & 15,5 & 856,25 & 88 & 27,25 & Even-aged \\
\hline 37 & $\mathrm{~N}$ & 1760 & 55 & 1400 & 22,9 & 862,70 & 103 & 28,43 & Even-aged \\
\hline 38 & E & 1880 & 40 & 1517 & 19,1 & 756,40 & 161 & 18,15 & Even-aged \\
\hline 39 & SE & 1790 & 25 & 1600 & 15,8 & 614,05 & 135 & 16,66 & Even-aged \\
\hline
\end{tabular}


Table 1. Continued.

\begin{tabular}{|c|c|c|c|c|c|c|c|c|c|}
\hline 40 & $\mathrm{~N}$ & 1875 & 40 & 1450 & 17,9 & 718,78 & 118 & 22,67 & Even-aged \\
\hline 41 & $\mathrm{~W}$ & 1860 & 55 & 6000 & 9,6 & 826,35 & $66^{*}$ & 26,96 & Uneven-aged \\
\hline 42 & NW & 1610 & 65 & 717 & 12,1 & 243,85 & 67 & 21,76 & Even-aged \\
\hline 43 & $\mathrm{NE}$ & 1790 & 65 & 1425 & 17,6 & 605,63 & 94 & 22,82 & Even-aged \\
\hline 44 & $\mathrm{E}$ & 1704 & 55 & 1750 & 18,0 & 834,55 & 89 & 28,02 & Even-aged \\
\hline 45 & SW & 1805 & 50 & 1625 & 13,0 & 343,38 & 95 & 17,69 & Even-aged \\
\hline 46 & NW & 1767 & 15 & 1250 & 21,0 & 916,57 & 107 & 24,78 & Even-aged \\
\hline 47 & $\mathrm{SE}$ & 1707 & 45 & 1525 & 14,0 & 713,45 & $104^{*}$ & 22,90 & Uneven-aged \\
\hline 48 & $\mathrm{SE}$ & 1725 & 60 & 1850 & 13,1 & 557,83 & 93 & 22,29 & Even-aged \\
\hline 49 & NW & 2070 & 50 & 650 & 15,1 & 363,60 & 99 & 18,46 & Even-aged \\
\hline 50 & $\mathrm{NE}$ & 2050 & 65 & 2600 & 13,0 & 311,43 & 70 & 25,52 & Even-aged \\
\hline 51 & NW & 820 & 65 & 875 & 16,2 & 353,00 & 91 & 20,33 & Even-aged \\
\hline 52 & $\mathrm{~N}$ & 960 & 68 & 850 & 15,4 & 491,80 & 118 & 16,77 & Even-aged \\
\hline 53 & $\mathrm{~N}$ & 1280 & 73 & 750 & 19,7 & 833,23 & 110 & 25,00 & Even-aged \\
\hline 54 & $\mathrm{~N}$ & 1160 & 82 & 775 & 16,8 & 453,90 & 99 & 23,67 & Even-aged \\
\hline 55 & $\mathrm{NE}$ & 1050 & 57 & 1025 & 17,1 & 624,08 & 129 & 17,64 & Even-aged \\
\hline 56 & $\mathrm{NE}$ & 1120 & 45 & 1025 & 14,1 & 430,35 & 122 & 13,69 & Even-aged \\
\hline 57 & NW & 870 & 42 & 975 & 15,4 & 381,00 & 90 & 20,00 & Even-aged \\
\hline 58 & $\mathrm{~N}$ & 940 & 76 & 950 & 15,5 & 475,05 & 120 & 16,90 & Even-aged \\
\hline 59 & $\mathrm{NE}$ & 1700 & 15 & 883 & 17,0 & 626,03 & $99^{*}$ & 27,28 & Uneven-aged \\
\hline 60 & $\mathrm{~N}$ & 1750 & 20 & 958 & 18,4 & 626,84 & $99^{*}$ & 26,88 & Uneven-aged \\
\hline 61 & $\mathrm{NE}$ & 1680 & 20 & 786 & 17,0 & 327,46 & 97 & 24,21 & Even-aged \\
\hline 62 & $\mathrm{E}$ & 1650 & 20 & 786 & 19,8 & 404,90 & 95 & 25,89 & Even-aged \\
\hline 63 & NW & 1119 & 75 & 1275 & 20,0 & 619,05 & $120^{*}$ & 22,50 & Uneven-aged \\
\hline 64 & NW & 1815 & 85 & 1367 & 15,8 & 499,10 & 101 & 23,44 & Even-aged \\
\hline 65 & SE & 1630 & 55 & 1475 & 14,4 & 430,90 & 111 & 16,82 & Even-aged \\
\hline 66 & $\mathrm{~N}$ & 1660 & 30 & 1975 & 21,0 & 1116,22 & 112 & 24,64 & Even-aged \\
\hline 67 & SW & 1624 & 25 & 1225 & 20,3 & 968,83 & 114 & 24,48 & Even-aged \\
\hline 68 & $\mathrm{NE}$ & 1765 & 30 & 2050 & 15,2 & 722,20 & 80 & 23,40 & Even-aged \\
\hline 69 & NW & 1780 & 65 & 1000 & 19,1 & 622,83 & 92 & 24,16 & Even-aged \\
\hline 70 & $\mathrm{~W}$ & 1820 & 95 & 1575 & 14,3 & 487,23 & 87 & 24,18 & Even-aged \\
\hline 71 & $\mathrm{E}$ & 1850 & 95 & 1500 & 15,6 & 572,53 & 119 & 19,08 & Even-aged \\
\hline 72 & $\mathrm{~N}$ & 1800 & 110 & 1275 & 15,9 & 588,83 & 118 & 18,54 & Even-aged \\
\hline 73 & $\mathrm{NE}$ & 1800 & 85 & 3500 & 11,5 & 432,37 & 61 & 20,89 & Even-aged \\
\hline 74 & $\mathrm{E}$ & 1710 & 100 & 1967 & 12,3 & 502,60 & 94 & 17,24 & Even-aged \\
\hline 75 & $\mathrm{NE}$ & 1055 & 30 & 4866 & 7,7 & 326,87 & 42 & 27,63 & Even-aged \\
\hline
\end{tabular}

*mean age of the stand

Speidel [17] suggested that, in order to establish stand structure using relative heights, four equal volumes of a tree should be selected. Therefore, the stem classification of all trees in the sample plots were determined within 4 quality categories: $\mathrm{A}=$ high-quality stem, $\mathrm{B}=$ middle-quality stem, $\mathrm{C}=$ low-quality stem, and $\mathrm{D}=$ high-quality firewood. 
Table 2. Stand homogeneity indexes (HI).

\begin{tabular}{|c|c|c|c|c|c|c|c|c|c|}
\hline Sample plot & HI & Sample plot & HI & Sample plot & HI & Sample plot & HI & Sample plot & HI \\
\hline 1 & 2,06 & 16 & 2,95 & 31 & 3,81 & 46 & 3,72 & 61 & 3,95 \\
\hline 2 & 2,64 & 17 & 4,16 & 32 & 3,13 & 47 & 1,92 & 62 & 2,55 \\
\hline 3 & 4,46 & 18 & 3,78 & 33 & 2,43 & 48 & 2,76 & 63 & 1,99 \\
\hline 4 & 7,15 & 19 & 2,22 & 34 & 2,95 & 49 & 1,95 & 64 & 2,44 \\
\hline 5 & 5,80 & 20 & 2,66 & 35 & 2,70 & 50 & 2,67 & 65 & 4,22 \\
\hline 6 & 4,70 & 21 & 3,67 & 36 & 2,61 & 51 & 3,34 & 66 & 2,62 \\
\hline 7 & 2,94 & 22 & 2,44 & 37 & 2,94 & 52 & 3,49 & 67 & 3,26 \\
\hline 8 & 3,68 & 23 & 3,50 & 38 & 3,11 & 53 & 2,00 & 68 & 3,18 \\
\hline 9 & 3,01 & 24 & 4,70 & 39 & 2,39 & 54 & 2,25 & 69 & 2,14 \\
\hline 10 & 2,98 & 25 & 4,30 & 40 & 3,69 & 55 & 3,71 & 70 & 2,82 \\
\hline 11 & 2,66 & 26 & 4,28 & 41 & 2,58 & 56 & 3,99 & 71 & 3,27 \\
\hline 12 & 3,45 & 27 & 2,56 & 42 & 2,60 & 57 & 6,74 & 72 & 3,15 \\
\hline 13 & 2,51 & 28 & 6,58 & 43 & 4,22 & 58 & 2,30 & 73 & 2,75 \\
\hline 14 & 3,20 & 29 & 4,54 & 44 & 2,15 & 59 & 1,88 & 74 & 3,40 \\
\hline 15 & 3,13 & 30 & 3,90 & 45 & 5,11 & 60 & 2,55 & 75 & 4,74 \\
\hline
\end{tabular}

In order to make comparisons between the stands and to establish the volume of the groups, one value factor has been given for every quality class, since the relationships between the qualifications in the stands are not exactly clear, $\mathrm{A}=1, \mathrm{~B}=3, \mathrm{C}=4$, and $\mathrm{D}=5$ value factors have been used for comparison. Therefore, the quality values of each sample area were formulated and stand quality values (SQV) were calculated using equation 2 [23].

$$
S Q V=\frac{A\left(N_{A}\right)+B\left(N_{B}\right)+C\left(N_{C}\right)+D\left(N_{D}\right)}{N_{A}+N_{B}+N_{C}+N_{D}}
$$

SQV: stand quality value

A, B, C, and D: quality categories

NA, NB, NC, and ND: the number of each quality category

The " $t$ " test is used for checking if the stand is homogeneous and if there is a variation among quality values of 59 samples from the even-age trees and 16 from different ages $[25,26]$. The variance analysis is used to determine if the stand structure (even-aged and uneven-aged), social levels (overstorey, mid-storey, undergrowth), and diameter class (I, II, III and IV) are coordinated with the stand quality value $[26,27]$.

\section{Results and Discussion}

Homogeneous index is calculated from the samples taken from 75 areas (Table 2). Homogeneous index values varied from 1,95 to $6,74(\mathrm{x}=3,53$ and $\mathrm{s}=1,13)$ in even-aged stands, and between 1,88-7,15 ( $\mathrm{x}=2,55$ and $\mathrm{s}=0,54)$ in uneven-aged stands. The independent $\mathrm{t}$ test is used to determine if there is any statistical difference between homogeneous index values of the stands in both groups. The results are listed in Table 3.

According to the results, one can conclude that the homogeneous index values of the even-aged stands are higher than those of the different age stands. Kapucu [8] published that the homogeneity index values are less than 2,50 for uneven-aged stand structure and higher than 2,50 for even-aged stand structure in the eastern Black Sea Region. De Camino [15] found the HI value in low thinning applied to even-aged stands between 4,0 and 10,0, and between 1,3 and 2,8 in uneven-aged stands. However the values ranges between 2,2 and 4,2, in the stands where high thinning was applied.

In comparisons of both groups in sample areas, a standard variation value for even-aged stands $(1,13)$ is higher than uneven-aged stands $(0,54)$. For both

Table 3. $t$ test results of homogeneity index values.

\begin{tabular}{|c|c|c|c|c|c|c|}
\hline Groups & $\mathrm{n}$ & $(\bar{x})$ & $\begin{array}{c}\text { Standard deviation } \\
(S)\end{array}$ & $\begin{array}{c}\text { Standard Error } \\
\left(S_{\bar{x}}\right)\end{array}$ & $t$ Statistic & Significant Level \\
\hline Even-aged & 59 & 3,53 & 1,13 & 0,15 & 4,906 & $\mathrm{p}<0,001$ \\
\hline Uneven-aged & 16 & 2,55 & 0,54 & 0,14 & & \\
\hline
\end{tabular}


Table 4. Stand quality values (SQV).

\begin{tabular}{|c|c|c|c|c|c|c|c|c|c|}
\hline Sample plot & SQV & Sample plot & SQV & Sample plot & SQV & Sample plot & SQV & Sample plot & SQV \\
\hline 1 & 3,78 & 16 & 3,80 & 31 & 4,62 & 46 & 3,50 & 61 & 3,20 \\
\hline 2 & 3,47 & 17 & 4,70 & 32 & 4,36 & 47 & 3,47 & 62 & 3,46 \\
\hline 3 & 3,68 & 18 & 4,77 & 33 & 2,16 & 48 & 4,12 & 63 & 3,74 \\
\hline 4 & 3,70 & 19 & 4,42 & 34 & 2,50 & 49 & 4,17 & 64 & 4,26 \\
\hline 5 & 3,91 & 20 & 4,43 & 35 & 3,79 & 50 & 4,52 & 65 & 4,08 \\
\hline 6 & 3,91 & 21 & 4,27 & 36 & 4,21 & 51 & 2,86 & 66 & 3,97 \\
\hline 7 & 4,02 & 22 & 4,32 & 37 & 3,63 & 52 & 3,43 & 67 & 3,43 \\
\hline 8 & 4,01 & 23 & 3,73 & 38 & 3,87 & 53 & 2,78 & 68 & 4,12 \\
\hline 9 & 4,52 & 24 & 4,32 & 39 & 3,81 & 54 & 3,49 & 69 & 3,77 \\
\hline 10 & 4,31 & 25 & 4,65 & 40 & 4,04 & 55 & 3,12 & 70 & 4,40 \\
\hline 11 & 4,74 & 26 & 4,66 & 41 & 4,63 & 56 & 3,57 & 71 & 4,01 \\
\hline 12 & 4,38 & 27 & 4,38 & 42 & 4,83 & 57 & 3,22 & 72 & 3,66 \\
\hline 13 & 4,21 & 28 & 3,15 & 43 & 3,80 & 58 & 3,61 & 73 & 4,52 \\
\hline 14 & 4,19 & 29 & 3,51 & 44 & 3,67 & 59 & 3,59 & 74 & 4,29 \\
\hline 15 & 2,60 & 30 & 4,46 & 45 & 3,80 & 60 & 3,53 & 75 & 3,08 \\
\hline
\end{tabular}

structures, $\mathrm{HI}=3$ value can be accepted as a general selective range.

Regression analysis is used to determine the stand characteristics related to stand homogeneity index values, and to show a mathematical number of the relationship. According to our results, there is no significant relationship between homogeneity index and elevation, and between aspect and stand volume. Structural and floristic heterogeneity could be changed by the influence of silvicultural applications and the roles of the edaphic factors in natural selection [28, 29]. Furthermore, structural heterogeneity could be explained by the variations of plant species, distributions of age, species in different elevation, and individual tree diameter classes $[30,31]$. In this study, the homogeneity index has a negative relationship with gradient and age, but the site index shows a positive relationship with mean height (Equation 3). Despite finding the low clarification coefficient at significant level $\alpha=0.01$, the regression is $\mathrm{R}^{2}=0.203$. This means that only $20.3 \%$ of the variation in stand homogeneity index could be explained by mean height, stand age, and the site quality index factors.
$H I=8.946-0.0127 X_{1}+0.178 X_{2}-0.0342 X_{3}-0.2012 X_{4}$

HI: Homogeneity index

$\mathrm{X} 1$ : slope

$\mathrm{X} 2$ : mean height

$\mathrm{X} 3$ : age

$\mathrm{X} 4$ : site quality

SQV values ranges between 2.16 and $4.83(x=3.94$ and $\mathrm{s}=0.58)$ in even-aged stands and 3.47 and 4.77 $(x=3.70$ and $\mathrm{s}=0.48)$ in uneven-aged stands (Table 4).

According to the results of the $\mathrm{t}$ test $(\mathrm{t}=1.49$, $\mathrm{p}=0.193)$, it was suggested that the mean values of the population were not different at the $\alpha=0.05$ significant levels. In other words, stand quality values of even-aged and uneven-aged stands are similar at a significance level of $\alpha=0.05(95 \%)$ (Table 5).

Siitonen et al. [32] emphasized the necessity of determining stand administration goals and evaluation of the goal as a factor during stand value definitions. But even-aged and uneven-aged stands in this study were administrated through the production goals. Consequently, the administrative factor wasn't

Table $5 . t$ test results of SQV.

\begin{tabular}{|c|c|c|c|c|c|c|}
\hline Groups & $\mathrm{n}$ & $(\bar{x})$ & $\begin{array}{c}\text { Standard deviation } \\
(\mathrm{S})\end{array}$ & $\begin{array}{c}\text { Standard Error } \\
\left(S_{\bar{x}}\right)\end{array}$ & $t$ Statistic & $\begin{array}{c}\text { Significant } \\
\text { Level }\end{array}$ \\
\hline Even-aged & 59 & 3,94 & 0,58 & 0,08 & 1,49 & $\mathrm{p}>0,05$ \\
\hline Uneven-aged & 16 & 3,70 & 0,48 & 0,12 & & \\
\hline
\end{tabular}


Table 6. SQV of social and diameter classes.

\begin{tabular}{|c|c|c|c|c|c|c|c|}
\hline \multirow[t]{2}{*}{ Sample plot } & \multicolumn{3}{|c|}{ SQV of Social classes } & \multicolumn{4}{|c|}{ SQV of diameter classes } \\
\hline & Overstorey & Mid-storey & Undergrowth & I & II & II & IV \\
\hline 1 & 2,34 & 3,30 & 4,88 & 4,67 & 3,89 & 3,50 & - \\
\hline 2 & 2,87 & 3,80 & 4,67 & 4,78 & 4,00 & 3,70 & - \\
\hline 3 & 3,93 & 4,56 & 5,00 & 5,00 & 4,65 & 4,50 & - \\
\hline 4 & 2,77 & 3,76 & 4,88 & 4,65 & 4,20 & 3,76 & - \\
\hline 5 & 4,50 & 4,89 & 5,00 & 4,78 & 4,66 & 4,00 & 3,65 \\
\hline 6 & 4,65 & 4,88 & 5,00 & 4,90 & 4,76 & 3,99 & 3,50 \\
\hline 7 & 2,99 & 3,97 & 4,97 & 4,73 & 3,17 & 3,50 & - \\
\hline 8 & 2,45 & 3,78 & 4,96 & 4,16 & 3,56 & - & - \\
\hline 9 & 4,25 & 4,66 & 5,00 & 5,00 & 4,56 & 4,04 & - \\
\hline 10 & 3,85 & 4,71 & 5,00 & 4,94 & 4,39 & 3,83 & 3,00 \\
\hline 11 & 4,24 & 4,71 & 5,00 & 4,99 & 4,53 & 3,79 & 4,50 \\
\hline 12 & 3,91 & 4,80 & 5,00 & 4,99 & 4,17 & 3,60 & - \\
\hline 13 & 3,58 & 4,58 & 5,00 & 5,00 & 4,00 & 3,50 & - \\
\hline 14 & 3,53 & 4,55 & 5,00 & 4,96 & 4,56 & 3,75 & - \\
\hline 15 & 2,28 & 3,21 & 5,00 & 3,27 & 2,26 & - & - \\
\hline 16 & 3,14 & 3,88 & 4,93 & 4,71 & 3,18 & 2,75 & - \\
\hline 17 & 4,25 & 4,60 & 4,98 & 5,00 & 4,59 & 4,31 & - \\
\hline 18 & 4,29 & 4,68 & 5,00 & 4,82 & 4,40 & 4,00 & - \\
\hline 19 & 3,36 & 4,19 & 5,00 & 4,79 & 3,91 & 3,17 & 4,25 \\
\hline 20 & 3,82 & 4,83 & 4,98 & 4,80 & 3,79 & 4,00 & - \\
\hline 21 & 3,87 & 4,44 & 5,00 & 5,00 & 4,29 & 3,86 & 3,75 \\
\hline 22 & 4,04 & 4,57 & 5,00 & 4,90 & 4,26 & 3,44 & - \\
\hline 23 & 3,53 & 4,19 & 5,00 & - & 4,10 & 3,62 & 2,92 \\
\hline 24 & 3,87 & 4,51 & 5,00 & 4,58 & 4,44 & 3,99 & 4,13 \\
\hline 25 & 4,31 & 4,66 & 5,00 & 4,88 & 4,59 & 4,44 & - \\
\hline 26 & 4,11 & 4,62 & 5,00 & 4,92 & 4,56 & 3,75 & - \\
\hline 27 & 3,79 & 4,54 & 5,00 & 5,00 & 4,34 & 3,77 & - \\
\hline 28 & 3,69 & 4,66 & 5,00 & 4,87 & 4,60 & 3,88 & - \\
\hline 29 & 4,12 & 4,77 & 5,00 & 4,98 & 4,70 & 4,00 & - \\
\hline 30 & 2,98 & 3,70 & 5,00 & 5,00 & 4,20 & 2,78 & - \\
\hline 31 & 4,33 & 4,76 & 4,98 & 5,00 & 4,60 & 4,50 & - \\
\hline 32 & 4,00 & 4,56 & 5,00 & 5,00 & 4,65 & 4,30 & - \\
\hline 33 & 3,56 & 4,30 & 4,99 & 4,65 & 4,23 & 4,12 & 4,00 \\
\hline 34 & 3,00 & 4,78 & 5,00 & 4,88 & 4,80 & 4,60 & - \\
\hline 35 & 4,30 & 4,60 & 4,76 & 4,60 & 3,60 & 3,40 & - \\
\hline 36 & 4,87 & 4,77 & 4,54 & 5,00 & 4,87 & 4,67 & - \\
\hline 37 & 3,54 & 3,40 & 3,00 & 4,78 & 4,50 & 4,44 & 4,30 \\
\hline 38 & 4,54 & 4,76 & 5,00 & - & 4,50 & 4,32 & 4,10 \\
\hline 39 & 3,54 & 4,55 & 4,76 & - & 4,50 & 4,20 & 4,00 \\
\hline
\end{tabular}


Table 6. Continued.

\begin{tabular}{|c|c|c|c|c|c|c|c|}
\hline 40 & 4,10 & 4,78 & 5,00 & 4,87 & 4,44 & 4,00 & 3,53 \\
\hline 41 & 2,66 & 3,98 & 4,97 & 4,88 & 3,40 & 2,76 & - \\
\hline 42 & 4,32 & 4,67 & 4,88 & 4,55 & 4,30 & 4,25 & - \\
\hline 43 & 3,56 & 4,00 & 4,54 & 4,90 & 3,66 & 3,10 & - \\
\hline 44 & 3,35 & 4,67 & 4,59 & 4,50 & 3,40 & 3,00 & - \\
\hline 45 & 4,51 & 4,57 & 4,98 & 5,00 & 4,79 & 3,20 & - \\
\hline 46 & 3,87 & 4,86 & 5,00 & 4,96 & 4,43 & 3,54 & - \\
\hline 47 & 2,40 & 3,87 & 5,00 & 4,76 & 4,50 & 3,00 & - \\
\hline 48 & 4,35 & 4,67 & 4,89 & 5,00 & 4,20 & 4,60 & - \\
\hline 49 & 4,69 & 4,68 & 4,99 & 4,87 & 4,69 & 4,50 & - \\
\hline 50 & 4,62 & 4,77 & 5,00 & 5,00 & 4,87 & 4,78 & - \\
\hline 51 & 3,55 & 3,89 & 5,00 & 4,98 & 4,30 & 3,76 & - \\
\hline 52 & 3,99 & 4,65 & 5,00 & - & 4,87 & 4,66 & 4,30 \\
\hline 53 & 3,79 & 4,77 & 4,99 & - & 4,56 & 3,97 & 3,40 \\
\hline 54 & 4,44 & 4,78 & 4,88 & 4,81 & 4,22 & 3,65 & - \\
\hline 55 & 3,43 & 4,78 & 5,00 & 5,00 & 4,55 & 3,45 & 2,54 \\
\hline 56 & 3,55 & 4,87 & 5,00 & - & 4,89 & 4,50 & 3,00 \\
\hline 57 & 4,12 & 4,56 & 5,00 & 4,98 & 4,50 & 4,00 & - \\
\hline 58 & 3,54 & 4,20 & 4,78 & 5,00 & 4,55 & 3,40 & 3,12 \\
\hline 59 & 2,56 & 3,20 & 5,00 & 4,68 & 4,00 & 2,76 & - \\
\hline 60 & 2,43 & 3,67 & 4,86 & 4,88 & 4,00 & 3,00 & - \\
\hline 61 & 3,59 & 4,30 & 4,71 & 5,00 & 4,78 & 4,00 & 3,76 \\
\hline 62 & 4,50 & 4,76 & 4,88 & 4,97 & 4,65 & 3,67 & 3,40 \\
\hline 63 & 2,54 & 3,32 & 5,00 & 5,00 & 4,30 & 3,30 & 3,00 \\
\hline 64 & 3,98 & 4,77 & 5,00 & 4,88 & 4,56 & 4,43 & 4,22 \\
\hline 65 & 4,43 & 4,78 & 4,98 & 5,00 & 4,78 & 4,65 & - \\
\hline 66 & 3,56 & 4,66 & 4,78 & - & 5,00 & 4,00 & 3,58 \\
\hline 67 & 3,20 & 4,34 & 4,67 & - & 4,89 & 3,55 & 3,10 \\
\hline 68 & 4,55 & 4,67 & 5,00 & 5,00 & 4,30 & 4,55 & - \\
\hline 69 & 3,54 & 4,65 & 4,79 & 4,99 & 4,76 & 3,20 & - \\
\hline 70 & 4,45 & 4,87 & 4,98 & 5,00 & 4,66 & 4,50 & - \\
\hline 71 & 3,45 & 4,00 & 5,00 & - & 5,00 & 4,79 & 4,67 \\
\hline 72 & 3,00 & 4,30 & 4,67 & - & 4,80 & 4,50 & 3,00 \\
\hline 73 & 4,55 & 4,78 & 5,00 & 5,00 & 4,69 & 4,50 & - \\
\hline 74 & 4,00 & 4,66 & 5,00 & 5,00 & 4,77 & 4,56 & - \\
\hline 75 & 3,50 & 4,80 & 5,00 & 5,00 & 3,50 & - & - \\
\hline
\end{tabular}

considered when establishing stand value classes. On the other hand, Michie [33] suggested the necessity of the detailed factor analysis because the single factor analysis is not sufficient for determining the real quality of the wood.
The distribution of stand quality value classes was listed in Table 6 based on social class distribution of IUFRO (overstory, mid-story, and undergrowth) and stem diameter classes (I. Stem diameter class: 8.0-19.9 cm, II. Stem diameter class: 20.0-35.9 cm, 
Table 7. $t$ test results of SQV according to social classes.

\begin{tabular}{|c|c|c|c|c|c|c|c|}
\hline \multicolumn{2}{|c|}{ Groups } & $\mathrm{n}$ & $(\bar{x})$ & $\begin{array}{c}\text { Standard deviation } \\
(S)\end{array}$ & $\begin{array}{c}\text { Standard Error } \\
\left(S_{\bar{x}}\right)\end{array}$ & $t \quad$ Statistic & Significant Level \\
\hline \multirow{2}{*}{ Overstorey } & Even-aged & 59 & 3,92 & 0,51 & 0,07 & \multirow{2}{*}{5,11} & \multirow{2}{*}{$\mathrm{p}<0,05$} \\
\hline & Uneven-aged & 16 & 3,02 & 0,65 & 0,163 & & \\
\hline \multirow{2}{*}{ Midstorey } & Even-aged & 59 & 4,56 & 0,34 & 0,04 & \multirow{2}{*}{4,55} & \multirow{2}{*}{$\mathrm{p}<0,05$} \\
\hline & Uneven-aged & 16 & 3,95 & 0,50 & 0,125 & & \\
\hline \multirow{2}{*}{ Undergrowth } & Even-aged & 59 & 4,90 & 0,28 & 0,04 & \multirow{2}{*}{$-0,73$} & \multirow{2}{*}{$\mathrm{p}>0,05$} \\
\hline & Uneven-aged & 16 & 4,95 & 0,09 & 0,02 & & \\
\hline
\end{tabular}

III. Stem diameter class: 36.0-51.9 cm, and IV. Stem diameter class: $52 \mathrm{~cm}$ and more; Table 6).

The average stand quality values (SQV) were calculated through the overstory, mid-story, and undergrowth. The results for even-aged stands are 3.92, 4.56, and 4.90, and for uneven-aged stands 3.02, 3.95, and 4.95 , respectively. The distribution of average SQV through stem diameter classes I-IV were calculated as 4.87, 4.44, 4.03, and 3.64 in even-aged stands and 4.80, $4.03,3.36$, and 3.69 in uneven-aged stands.

Depending on the t-test results that were used for distributing SQV values through social classes, in even-aged and uneven-aged stands individuals in mid-story and overstories were different from each other, but between the individuals in undergrowth, there were no differences at the 0.05 significant level $\alpha$ (Table 7). Hanewinkel and Pretzch [34] studied the Norway spruce using the same modeling employed in this work and found no quality difference between the individuals in undergrowth during transformation of even-aged stands and uneven-aged stands (Table 7).

According to Table 7, SQV values are increased from overstory to mid-story to undergrowth, in other words, stem quality of the stands declines from overstory to mid-story and undergrowth. By evaluations from the point of view of even-aged and unevenaged stands, a significant difference was determined among the individuals only in overstory and mid-story. In undergrowth, among the individuals in uneven-aged and even-aged stands, no significant difference was detected.

There is no difference in SQV between the first stem diameter class of even-aged and unevenaged stands at significance level $\alpha=0.05$. But in the second and third stem diameter classes a significant difference was detected (Table 7). On the other hand, Buongiorno [35] suggested that individuals at thin stem diameter class, which enrich biological diversity, should not be taken into consideration in both stands, which requires keeping the balance between production for maximum benefit from the even-aged and unevenaged stands and to further sustain biological diversity in uneven-aged stands. Similarly, he established the economical value of the individuals that fall into the thin-diameter class and thus such undergrowth classes could not be taken into consideration if a number to assess the quality of trees or wood developed.

During the management of the existing forests that are populated with various ages of trees, it is necessary to reserve the thick individuals to produce high-quality wood [36-39], but as a result of the natural regeneration, the thin individuals are substituted with thick ones [40-42]. Nevertheless, tree quality is reduced when the basal area increased [43-47] and as a result of changes the biodiversity of the forest, stand structure, and quality classification are also continuously changed.

SQVs in Table 7 are reduced from first to third class in terms of stem diameter. (By the way, the stem quality of thick individuals is higher than that of the thin individuals.) On the other hand, if you compare the second and third stem diameter classes between the even-aged and uneven-aged stands it was clear that the quality of the even-aged spruce stands is worse than the uneven-aged stands.

According to the regression analysis, mathematical models, and SQV, there are no statistically significant differences between aspect and slope, but there is a positive correlation among the height, stand volume, and age. Thus according to the data presented in this paper one can conclude that when the height and stand volume increases, SQV also inclines; however, when the stand age increases, SQV is reduced. There is a negative correlation between stand age and SQV. Accusative coefficient of regression model was calculated as a R2 $=0.303$. As a function of height, stand volume, and stand age, SQV can be calculated by the equation below:

$$
\begin{gathered}
\mathrm{SQV}=3.089+0.007474 \mathrm{X} 1+0.0003547 \mathrm{X} 2 \\
-0.00886 \mathrm{X} 3
\end{gathered}
$$

X1: altitude

$\mathrm{X} 2$ : volume

$\mathrm{X} 3$ : age 


\section{Conclusions}

No statistically significant differences were found between the homogeneity index value of even-aged and uneven-aged stands.

- The homogeneity index values of the even-aged are higher than uneven-aged stands, indicating that the uneven-aged trees are more homogenous.

- HI = 3 was found to be a homogeneity index value that can be used to distinguish even and uneven-aged stands.

- In the normal canopy pure Oriental spruce stands, we found that there is a positive correlation between homogeneity and age and side index of the trees.

- According to stand quality value, no difference was detected between even-aged and uneven-aged stands.

- In a normal canopy of pure Oriental spruce stands, the social class of the trees statically affects the stand quality value, then we can conclude that from the over story to undergrowth, stem quality is reduced.

- In differentiation of even-aged and uneven-aged stands, SQV had been shown to be different only in over-story and mid-story. Namely, in the even-aged stands, the stem quality of the individuals at over and mid-stories are higher quality than the individuals in even-aged stands.

- In the normal canopy of pure Oriental spruce stands, the diameter category of the trees statically affect the stand value class. SQV is reduced from the thin diameters to thick diameters, and also the stand stem quality increases depending on the increases of individuals in thick diameter class.

- In normal canopy pure spruce stands, stem quality increases by age, but is reduced by the increase of height and stand volume.

A quantitative number to determine stand structures and stand quality values can be used for diagnosing many forestry activities, such as silvicultural planning, administration-marketing, and forestry policy.

By determining homogeneity index, the stand structures can be comprehended and annual changes in stand structures can be monitored by age, and the success criteria can be established numerically.

In regeneration works, it is important to select the seed trees considering the stand quality value, which helps increase the quality of the stand.

For controlling the fit of the relative lengths used to determine the stand value classes, must be defined if resulted in equal volumes by calculating the actual volumes in sufficient numbers of the sample trees.

In good ecological conditions with suitable stand structure in high site quality, uneven aged administration principles should be practiced and stands with higher stem quality can be produced.

\section{Acknowledgements}

I wish to thank the Scientific and Technological Research Council of Turkey (TUBITAK) for financial support for the TOGTAG-TARP 2051 project, of which this study a part.

\section{Conflict of Interest}

The author declares no conflict of interest.

\section{References}

1. KÜÇÜK M., Natural spreading area of the oriental spruce, oriental spruce handbook, Ormancılık Araştırma Enstitüsü Yayınları, El Kitabı Dizisi: 5, Ankara, 78, 1989 [in Turkish].

2. FARJON A., Picea orientalis, oriental spruce, The IUCN Red List of Threatened Species 2013: e.T42332A2973275, 2013.

3. ORMAN GENEL MÜDÜRLÜĞÜ, Forest Enventery of Turkey - 2015, Orman Bakanlığı, Ankara, 14, 2015 [In Turkish].

4. DEMIRCI A., YAVUZ H., ÜÇLER A.Ö., OKTAN E., YÜCESAN Z., Standing establishments in pure east spruce forests in Turkey, growth and growth relationships and silvicultural recommendations. TÜBİTAK- TOGTAG, Proje No: TARP-2051, 169, Trabzon, 2002 [In Turkish].

5. MARTÍNEZ PASTUR G.J., CELLINI J.M., LENCINAS M.V., PERI P.L., Stand growth model using volume increment/basal area ratios, Journal of Forest Science, 54, (3), 102, 2008.

6. LIN C.J., LAIHO O., LAHDE E., Norway spruce (Picea abies L.) regeneration and growth of understory trees under single-tree selection silviculture in Finland, Eur. J. Forest Res., 131, 683, 2012.

7. FORRESTER D.I., The spatial and temporal dynamics of species interactions in mixed-species forests: From pattern to process, Forest Ecology and Management, 312, 282, 2014.

8. KAPUCU F., Evaluation of some species like Oriental sprice (Picea orientalis (L.) Carr.), Scots pine (Pinus silvestris L.), Eastern Black Sea Fir (Abies nordmanniana Spach.) and Oriental beech (Fagus orientalis Lipsky.) in Eastern Black Sea Region of Turkey. KTÜ Orman Fakültesi, Amenajman Anabilim Dall, Doçentlik Tezi, Trabzon, 1978 [In Turkish].

9. SNIDERHAN A.E., BALTZER J.L., Growth dynamics of black spruce (Picea mariana) in a rapidly thawing discontinuous permafrost peatland, J. Geophys. Res. Biogeosci., 121, 2988, 2016.

10. BALANDA M., Spatio-temporal structure of natural forest: A structural index approach, Beskydy, 5 (2), 163, 2012.

11. YUANFA L., GANGYING H., ZHONGHUA Z., YANBO, H., SHAOMING Y., Spatial structural characteristics of three hardwood species in Korean pine broad-leaved forest - Validating the bivariate distribution of structural parameters from the point of tree population, Forest Ecology and Management, 314, 17, 2014. 
12. CONDÉS S., DEL RIO, M., STERBA, H., Mixing effect on volume growth of Fagus sylvatica and Pinus sylvestris is modulated by stand density, Forest Ecology and Management, 292, 86, 2013.

13. LIIRA J., KOHV K., Stand characteristics and biodiversity indicators along the productivity gradient in boreal forests: Defining a critical set of indicators for the monitoring of habitat nature quality, Plant Biosystems - An International Journal Dealing with all Aspects of Plant Biology, 144 (1), 211, 2010.

14. MOORE J.R., LYON A.J., SEARLES G.J., VIHERMAA L.E., The effects of site and stand factors on the tree and wood quality of Sitka spruce growing in the United Kingdom. Silva Fennica, 43 (3), 383, 2009.

15. De CAMINO M.R., Zur bestimmung der bestandeshomogenität, Allgemeine Forst-und Jagdzeitung, 147. Jg. 54-58 s., Frankfurt, 1976. [In German]

16. GEHRLEIN W.V., Consistency in measures of social homogeneity: a connection with proximity to single peaked preferences, Quality \& Quantity 39, Kluwer Academic Publishers, Netherlands, 147, 2004.

17. SPEIDEL G., Planung im forstbetrieb, Paul Parey Verlag, Hamburg und Berlin, 258, 1972. [In German].

18. AAKALA T., KUULUVAINEN T., WALLENIUS T., KAUHANEN H., Contrasting patterns of tree mortality in late-successional Picea abies stands in two areas in northern Fennoscandia, Journal of Vegetation Science, 20, 1016, 2009.

19. KUULUVAINEN T., HOFGAARD A., AAKALA T., JONSSON B.G., North Fennoscandian mountain forests: History, composition, disturbance dynamics and the unpredictable future, Forest Ecology and Management, 385, 140, 2017.

20. KALLIO M.H., KRISNAWATI H., ROHADI D., KANNINEN, M., Mahogany and Kadam planting farmers in south Kalimantan: The link between silvicultural activity and stand quality, Small-scale Forestry, 10, 115, 2011.

21. AAKALA T., FRAVER S., D'AMATO A.W., PALIK B.J. Influence of competition and age on tree growth in structurally complex old-growth forests in northern Minnesota, USA, Forest Ecology and Management, 308, 128, 2013.

22. TOOCHI E.C., Forest and environment: Developments in global change ecology, Forest Res. Eng. Int. J., 1 (3), 00016, 2017.

23. KAPUCU F., YAVUZ H., GÜL A.U., Evaluation of homogeneity status and body characteristics in the stands (Fraxinus angustifolia WAHL.)., Turkish Journal of Agriculture and Forestry, 25, 433, 2001 [In Turkish].

24. DEMIRCI A., ÜÇLER A.Ö., YAVUZ H., OKTAN E., YÜCESAN Z., Establishment of the stand structures of pure oriental spruce (Picea orientalis L.Link.) stands by the homogeneity indexes, Third Balkan Scientific Conference, 2-6 October 2001, 1, 350, Sofia, 2001.

25. WALKER X., JOHNSTONE J.F., Widespread negative correlations between black spruce growth and temperature across topographic moisture gradients in the boreal forest, Environ. Res. Lett. 9, 064016, 1, 2014.

26. McKILLUP S., Statistics Explained: An introductory guide for life scientists, $2^{\text {nd }}$ ed., Cambridge University Press, London, UK, 87, 2012.

27. VARELA R.A.D., ALVAREZ P.A., VARELA E.D., IGLESIAS S.C., Prediction of stand quality characteristics in sweet chestnut forests in NW Spain by combining terrain attributes, spectral textural features and landscape metrics, Forest Ecology and Management, 261, 17, 2011.

28. BARTELS S.F., CHEN H.Y.H. Is understory plant species diversity driven by resource quantity or resource heterogeneity? Ecology, 91 (7), 1931, 2010.

29. SILVER E.J., D’AMATO A.W., FRAVER S., PALIK B.J., BRADFORD J.B., Structure and development of oldgrowth, unmanaged second-growth, and extended rotation Pinus resinosa forests in Minnesota, USA, Forest Ecology and Management, 291, 110, 2013.

30. BARBIER N., COUTERON P., PROISY C., MALHI Y. AND GASTELLU-ETCHEGORRY J.P., The variation of apparent crown size and canopy heterogeneity across lowland Amazonian forests. Global Ecology and Biogeography, 19, 72, 2010.

31. FORRESTER D.I., KOHNLE U., ALBRECHT A.T., BAUHUS J., Complementarity in mixed-species stands of Abies alba and Picea abies varies with climate, site quality and stand density, Forest Ecology and Management, 304, 233, 2013.

32. SIITONEN P., TANSKANEN A., LEHTINEN A., Method for selection old-forest reserves, Conservation Biology, 16, 1398, 2002.

33. MICHIE B.R., Uneven-aged stand management and the value of forest land, For. Sci., 31, 116. 1985.

34. HANEWINKEL M., PRETZSCH H., Modeling the conversion from even-aged to uneven-aged stands of Norway spruce (Picea abies L. Karst.) with a distancedependent growth simulator, Forest Ecology and Management, 134, 55, 2000.

35. BUONGIORNO J., Quantifying the implications of transformation from even to uneven-aged forest stands, Forest Ecology and Management, 151, 121, 2001.

36. GONZALEZ P., NEILSON R.P., LENIHAN J.M., DRAPEK R.J., Global patterns in the vulnerability of ecosystems to vegetation shifts due to climate change, Global Ecology and Biogeography, 19, 755, 2010.

37. DURKAYA, B., DURKAYA, A., MAKINECI, E., KARABURK, T., Estimating above-ground biomass and carbon stock of individual trees in uneven-aged Uludag fir stands, Fresenius Environ. Bull., 22 (1), 428, 2013.

38. BURTON P.J., BERGERON Y., BOGDANSKI B.E.C., JUDAY G.P., KUULUVAINEN T., MCAFEE B.J., OGDEN A.E., TEPLYAKOV V.K., ALFARO R.I., FRANCIS D.A., GAUTHIER S., HANTULA J., Sustainability of boreal forests and forestry in a changing environment G. Mery, P. Katila, G. Galloway, R.I. Alfaro, M. Kanninen, M. Lobovikov, and J. Varjo, editors. Forests and Society - Responding to Global Drivers of Change. International Union of Forest Research Organizations, Vienna, Austria, IUFRO World Series, Chapter 14, 249, 2010.

39. YÜCESAN Z., ÜÇLER A.Ö., OKTAN E., Stability and stand value in high mountain forests in Firtına Valley, Kastamonu Univ., Journal of Forestry Faculty 13 (1), 117, 2013 [In Turkish].

40. KUULUVAINEN T., Conceptual models of forest dynamics in environmental education and management: keep it as simple as possible, but no simpler, Forest Ecosystems, 3, 18, 2016.

41. YUANFA L., SHAOMING Y., GANGYING H., YANBO H., ZHONGHUA Z., Spatial structure of timber harvested according to structure-based forest management, Forest Ecology and Management, 322, 106, 2014. 
42. KOPEĆ D., HALLADIN-DĄBROWSKA A., ZAJĄC I., Flora dynamics in a strictly protected nature reserve, Polish J. of Environ. Stud. 20, (1), 107, 2011.

43. PRETZCH H, Forest Dynamics, Growth and Yield, Springer Verlag, Berlin, Hiedelberg, 337, 2009.

44. BARBIER N., COUTERON P., PROISY C., MALHI Y., GASTELLU-ETCHEGORRY J.P., The variation of apparent crown size and canopy heterogeneity across lowland Amazonian forests, Global Ecology and Biogeography, 19, 72, 2010.

45. LEŠO P., LEŠOVÁ A., KROPIL R., KANUCH P., Response of the dominant rodent species to close-to-nature logging practices in a temperate mixed forest. Ann. For. Res. 59 (1), 259, 2016.
46. WEN W., YUANMAN H., YUEHUI L., JIPING G. LONG C., YU C., ZAIPING X., Plant diversity and vegetation structures in the understory of mixed boreal forests under different management regimes, Polish J. of Environ. Stud. 25, (4), 1749, 2016.

47. ÖZEL H.B., ERTEKİN M., YILMAZ M., KIRDAR E., Factors affecting the success of natural regeneration in oriental beech (Fagus orientalis Lipsky) forests in Turkey, Acta Silv. Lign. Hung., 6, 149, 2010. 